УДК 342.6

DOI https://doi.org/10.32849/2663-5313/2020.8.34

\title{
Сергій Федоров,
}

канд. юрид. наук

дочент кафедри фінансового права

Національного юридичного університету імені Ярослава Мудрого

\section{ДЕРЖАВНИЙ КОНТРОЛЬ У СФЕРІ ТРЕЙДИНГОВИХ ОПЕРАЦІЙ ІЗ КРИПТОВАЛЮТАМИ: ФІНАНСОВО-ПРАВОВИЙ АСПЕКТ}

Стаття присвячена проведенню загального дослідження можливих перспектив і шляхів запровадження державного контролю над так званими трейдинговими операчіями з криптовалютами у фінансово-правовому аспекті. Автором аналізуються окремі особливості правової регламентаціі використання криптовалют (віртуальних валют, криптоактивів) як фінансових інструментів, провадження діяльності з торгівлі криптовалютами та їх обміну на фіатні гроші. У иьому контексті вивчається новий термінологічний апарат, що використовується в иій сфері, зокрема поняття «майнінг криптовалют», «трейдинг криптовалют», «блокчейн» тощо.

Автор статті доходить висновку, що сьогодні криптовалюти є не тільки засобом платежу, що широко використовується в різних сферах, а й фінансовим інструментом, ио активно «торгується» на спеціалізованих криптобіржах і застосовується в операціях із обміну на фіатні гроші. 3 метою впорядкування таких відносин, забезпечення їх стабільності, гарантування захисту прав та інтересів учасників цих відносин окремі країни світу пішли шляхом визнання криптовалют відповідними фінансовими інструментами, у зв'язку з чим упорядкування відносин із торгівлі й обміну криптовалют здійснюється за аналогією з правовим регулюванням біржового ринку, використання иінних паперів та інших фінансових інструментів. Відповідно, і державний контроль у иій сфері здійснюється за аналогією з державним контролем аналогічних «звичайних біржових відносин».

Вивчаються необхідність і можливі шляхи запровадження державного контролю за такими фінансовими операчіями й в Украйні, для чого проведено дослідження міжнародного досвіду законодавчого впорядкування трейдингових операцій із криптовалютами, зокрема аналізуються нормативно-правові й рекомендаційні акти США, Японії, Австралї̈, Великобританії, Канади в иій сфері. На підставі проведеного дослідження визначено загальні тендениії здійснення державного контролю за трейдинговими операціями з криптовалютами як із фінансовими інструментами в цих країнах світу. Досліджуються можливості запровадження вказаного закордонного досвіду державного контролю за трейдинговими операчіями з криптовалютами як за фінансовими операціями в Україні.

Ключові слова: криптовалюти, криптовалютні операції, трейдингові операції, фінансові інструменти, державний контроль

Постановка проблеми. Натепер по всьому світу все актуальнішими стають питання обігу криптовалют. Досить поширеною є позиція, що криптовалюти є не тільки засобом платежу й накопичення блага, а й «товаром», об'єктом господарських операцій. У зв'язку із цим важливою є не лише проблематика правового регулювання відносин із використання криптовалют як платіжного засобу, а й відносин із торгівлі криптовалютами та їх обміну на фіатні гроші.

В обігу все частіше використовуються поняття: «трейдинг криптовалют», «криптовалютний трейдинг», «трейдингові операції з криптовалютами». Їх поява зумовлена виникненням відносин із торгівлі та обміну криптовалют, що здійснюються, зокрема, на спеціальних біржах.

Як уже досліджено нами раніше, відносини з використання криптовалют на цей час не $€$ належним чином урегульованими в більшості країн світу. В Україні ж лише тривають дискусії щодо необхідності запровадження правового регулювання відносин із використання криптовалют у державі [1, с. 221]. Важливим аспектом упорядкування ринку криптовалют $\epsilon$ запровадження злагодженої системи державного контролю за такого роду операціями особливо в контексті того, що такі операції мають фінансовий характер. У зв'язку із цим питання торгівлі й обміну криптовалют підлягають самостійному 
дослідженню, зокрема, у контексті їх державного контролю як фінансових операцій.

Окремі питання використання й обігу криптовалют вивчали, зокрема, С.В. Воронцова, М.В. Гребенюк, Б.В. Деревянко, І.М. Доронін, А.Т. Ковальчук, О.О. Лов'як, С.С. Пилипишин, В.В. Посполітак, С.Г. Стеценко, О.В. Таволжанський, В.А. Устименко й інші. У сфері економіки проблематику обігу та використання криптовалют досліджували Н.В. Архірейська, Л.О. Баластрик, Р.Й. Бачо, О.І. Береславська, С.В. Волосович, Ю.В. Гава, Д.М. Гладких I.І. Гусєва, М.І. Диба, В.В. Зимовець, А.С. Карнаушенко, В.В. Корнєєв, В.М. Костюченко, І.В. Краснова, Т.О. Кричевська, Л.М. Надієвець, О.С. Новак, В.С. Петренко, О.М. Петрук М.I. Савлук, Т.С. Смовженко, В.Г. Сословський, Н.С. Танклевська, Г.Г. Чмерук, О.Г. Чумаченко, О.М. Шаров та інші.

Указані автори в роботах також прямо чи опосередковано вивчають питання торгівлі й обміну криптовалют, хоча комплексне дослідження цього питання, у тому числі крізь призму державного контролю, на цей час відсутне

Метою статті є дослідження перспектив i можливостей здійснення державного контролю за трейдинговими операціями як за фінансовими операціями в Україні.

Виклад основного матеріалу. Сьогодні існує два способи набуття у власність криптовалют: майнінг криптовалют і їх купівля [2]. У спеціальній літературі під майнінгом розуміється процес вирішення криптографічних головоломок з використанням обчислювальних потужностей комп'ютера або спеціалізованих пристроїв з метою обслуговування мережі Bitcoin [3, с. 12]. Аналогічне визначення майнінгу надавалося й у проектах законів України щодо врегулювання відносин з обігу криптовалют: майнінг - це обчислювальні операції, які здійснює майнер за допомогою власного та/або орендованого спеціалізованого обладнання з метою забезпечення працездатності й безпеки системи блокчейн, і залежно від умов системи блокчейн отримує винагороду системи блокчейн [4]; майнінг - діяльність фізичних і юридичних осіб із проведення математичних розрахунків з метою отримання винагороди у вигляді одиниць криптовалюти [5].

Набуття ж криптовалют у власність на підставі купівлі-продажу здійснюється зокрема, через спеціалізовані біржі. У рамках цих правовідносин виникає так званий «криптовалютний трейдинг» - систематична діяльність спекулятивного характеру, що здійснюється на криптовалютній біржі 3 метою отримання прибутку; мова йде про постійні операції з обміну однієї криптовалюти на іншу та/або на фіатні гроші [3, с. 11].

Можливість провадження контролю будь-яких відносин зумовлюється встановленням правового регулювання таких правовідносин, адже те, щодо чого не встановлені жодні вимоги, не може бути й проконтрольовано. Україна сьогодні входить у ТОП-10 країн світу за кількістю користувачів Bitcoin, в Україні провадить свою діяльність найбільше в СНД біткоін-агентство Kuna, одним із проектів якого $є$ криптовалютна біржа [3, с. 85]. При цьому трейдингові операції з криптовалютами в Україні жодним чином не врегульовані в правовому стосунку. Варто зазначити, що зареєстровані у Верховній Раді України законопроекти, спрямовані на встановлення правового регулювання в тому числі й відносин з торгівлі та обміну криптовалют на фіатні гроші («Про обіг криптовалюти в Україні», «Про стимулювання ринку криптовалют та їх похідних в Україні»), відкликані у зв'язку з необхідністю їх доопрацювання [4; 5].

Отже, здійснювати контроль за такого роду операціями в Україні сьогодні не видається можливим. Однак не можна не погодитися, що все зростаюче значення криптовалют та операцій із ними в сучасному світі на фоні достатньої фактичної розвиненості ринку криптовалют, активної торгівлі ними й обміну на фіатні гроші в Україні потребуватиме впорядкування цього виду правовідносин на законодавчому рівні найближчим часом. I саме правова наука має стати основою для розроблення належного правового регулювання відповідної групи правовідносин. 3 огляду на новизну відносин із торгівлі та обміну криптовалютами й державного контролю за ними, проведення наукових досліджень у цій сфері найбільш доцільно розпочати з вивчення закордонного досвіду.

Зокрема, в авангарді країн, у яких запроваджено правове регулювання трейдингових операцій із криповалютами, перебуває Японія, у якій з 1 травня 2020 набули чинності чергові зміни, унесені до таких національних законів, як Акт про платіжні сервіси (Payment Services Act) та Акт про фінансові інструменти й біржі (Financial Instruments and Exchange Act) [6]. Відповідно до запроваджених змін, маржинальна торгівля криптоактивами та інші транзакції з похідними криптоактивами регулюються загальними правилами здійснення операцій із похідними фінансовими інструментами. Кастодіальна діяльність, пов'язана 3 криптоактивами, підлягає ліцензуванню. За недобросовісну торгівлю криптоактивами на біржі можуть накладатися заборони контролюючим органом [6]. 
У штаті Нью-Йорк прийнято спеціальний нормативно-правовий акт щодо врегулювання торгівлі віртуальними валютами. Так, у червні 2015 року Департаментом фінансових послуг штату Нью-Йорк, відповідно до Закону про фінансові послуги НьюЙорка, затверджене власне положення про віртуальну валюту 23 NYCRR Part 200 [7]. У цьому положенні, зокрема, передбачається, що жодна особа в штаті Нью-Йорк не має права здійснювати комерційну діяльність із віртуальними валютами без отримання ліцензії від уповноваженого органу в порядку, визначеному в цьому нормативноправовому акті. При цьому такі особи навіть за умови отримання ліцензії не мають право здійснювати фідуціарну діяльність [7].

Під комерційною діяльністю 3 віртуальними валютами у вищевказаному нормативно-правовому акті розуміється така діяльність:

- отримання віртуальної валюти з метою iii подальшого передання іншим особами, крім випадків, коли такі транзакції здійснюються без мети отримання прибутку з передачею віртуальної валюти за її номінальною вартістю;

- зберігання віртуальної валюти від імені інших осіб;

- надання посередницьких послуг клієнтам із купівлі та продажу віртуальної валюти;

- надання посередницьких послуг з обміну віртуальних валют;

- управління, адміністрування та випуск віртуальної валюти [7].

Досить упорядкованим і системним $\epsilon$ правове регулювання відносин із торгівлі й обміну криптоактивами в Австралії. Австралійська комісія 3 інвестицій і цінних паперів (Australian Securities and Investments Commission) на офіційному сайті надає роз'яснення, що у випадку, коли платформа (біржа) має справи з криптоактивами як із фінансовими продуктами в розумінні відповідних законодавчих актів Австралії, такий суб'єкт має отримувати Австралійську ліцензію професійного учасника ринку цінних паперів (Australian market license) [8].

у Великобританії перші кроки на шляху впорядкування відносин із торгівлі й обміну криптовалют пов'язані $з$ державною політикою 3 боротьби 3 легалізацією (відмиванням) доходів, отриманих злочинним шляхом, і з фінансуванням тероризму. Натепер Управлінням фінансового нагляду Великобританії прийнято рекомендаційний документ «Відшкодування витрат на нагляд за криптобізнесом, відповідно до запропонованих правил протидії відмиванню грошей: пропозиція по зборах» (Recovery of Costs of Supervising Cryptoasset Businesses Under the Proposed Anti-money Laundering Regulations: Fees Proposals) [9]. У цьому документі надано рекомендації щодо суб'єктів підприємницької діяльності, які планують здійснювати операції з криптовалютами, зокрема провайдерів криптобірж, операторів криптобанкоматів, провайдерів криптогаманців, емітентів криптоактивів тощо [9].

У цьому документів таким суб'єктам рекомендується: 1) подати заяву на реєстрацію криптокомпанії в Управлінні фінансового нагляду, 2) перебувати на обліку в Управлінні фінансового нагляду з погляду протидії відмиванню коштів і фінансуванню тероризму (AntiMoney Laundering and Countering Financing of Terrorism), 3) сплатити реєстраційний внесок, 4) щорічно сплачувати мито [9].

У Канаді в червні 2020 року набув чинності законодавчий акт, яким унесено зміни до деяких нормативно-правових актів у сфері протидії легалізації доходів, отриманих злочинним шляхом (відмивання грошей), і фінансуванню тероризму (Regulations Amending Certain Regulations Made Under the Proceeds of Crime (Money Laundering) and Terrorist Financing) [10]. Цим актом легалізована діяльність компаній у сфері криптовалют (криптобірж) із обміну криптовалют на фіатні гроші та на інші криптовалюти, а також із переказів криптовалют. Указані компанії офіційно прирівнюються до суб'єктів господарювання, що надають грошові послуги [10].

3 набуттям чинності вищевказаних змін у Канаді криптобіржі підлягають обов'язковій реєстрації, а також на них покладається обов'язок повідомляти контролюючий орган влади про всі операції з криптовалютами, що перевищують в еквіваленті 10000 канадських доларів [10].

Ураховуючи наведений вище досвід деяких зарубіжних країн, можемо стверджувати, що запровадження державного контролю над трейдинговими операціями 3 криптовалютами як за фінансовими операціями можливе за такими основними напрямами:

- установлення обов'язкової реєстрації професійних учасників відносин із трейдингу криптовалют у спеціалізованих державних реєстрах за аналогією 3 реєстром професійних учасників ринку цінних паперів;

- установлення обов'язку для професійних учасників відносин із трейдингу криптовалют отримувати документи дозвільного характеру (наприклад, ліцензії) за аналогією 3 дозвільними документами для професійних учасників ринку цінних паперів; 
- установлення права спеціалізованих органів державної влади здійснювати нагляд за законністю і «справедливістю» операцій за участі професійних учасників відносин iз трейдингу криптовалют, надання таким органам повноважень на зупинення чи скасування окремих операцій, зупинення чи припинення діяльності таких суб'єктів;

- установлення обов'язку професійних учасників відносин із трейдингу криптовалют здійснювати фінансовий моніторинг трейдингових операцій із криптовалюватами в тому числі й шляхом повідомлення про здійснення окремих із них (за ознаками суми таких операцій) відповідних контролюючих органів держави.

\section{Висновки}

Провівши аналіз досвіду окремих зарубіжних країн у сфері здійснення державного контролю за трейдинговими операціями 3 криптовалютами, можемо зробити такі ключові висновки щодо напрямів і шляхів запровадження державного контролю над трейдинговими операціями 3 криптовалютами як за фінансовими операціями в Україні:

1. Першим та основним кроком на шляху запровадження державного контролю над трейдинговими операціями 3 криптовалютами є визначення на законодавчому рівні правового статусу криптовалют, упорядкування на нормативно-правовому рівні основних напрямів їх використання, оскільки неможливо контролювати те, стосовно чого не встановлені жодні вимоги.

2. 3 огляду на фінансово-правову природу трейдингових операцій із криптовалютами, а також загальноприйняті правила юридичної (нормотворчої) техніки, досить обгрунтованою є позиція прирівнювання трейдингових операцій із криптовалютами до операцій із загальноприйнятими фінансовими інструментами шляхом унесення відповідних змін до законодавства у сфері обігу цінних паперів і функціонування фондового ринку (в Україні, зокрема, таким нормативно-правовим регулятором $€$ Закон України «Про цінні папери та фондовий ринок»).

3. Державний контроль за трейдинговими операціями 3 криптовалютами як за фінансовими операціями повинен грунтуватися на забезпеченні не лише дотримання професійними учасниками таких операцій вимог законодавства у сфері обігу цінних паперів та інших фінансових інструментів, a й вимог законодавства у сфері протидії легалізації доходів, отриманих злочинним шляхом, і у сфері протидії фінансуванню тероризму, оскільки натепер криптовалютний ринок, на жаль, досить часто використовується саме з такою метою.

\section{Список використаних джерел:}

1. Федоров С. Державний фінансовий контроль і криптовалютні операції: поза межами права. Підприємство, господарство і право. 2019. № 3. C. 218-222.

2. Украинским криптовалютным трейдерам придется платить 19,5\% подоходного налога. URL: https://bits.media/treydery-ukrainy-dolzhnyplatit-nalog-na-pribyl-19-5-s-kriptovalyutnykhoperatsiy/.

3. Правовое регулирование криптовалютного бизнеса. 2017. 101 с. URL: https://axon.partners/ wp-content/uploads/2017/02/Global-Issues-ofBitcoin-Businesses-Regulation.pdf.

4. Про обіг криптовалюти в Україні : Проект Закону України від 06.10.2017 № 7183. База даних «Законодавство України» / Верховна Рада Украӥни. URL: http://w1.c1.rada.gov.ua/pls/zweb2/ webproc4_1?pf3511=62684.

5. Про стимулювання ринку криптовалют та їх похідних в Україні : Проект Закону України від 10.10.2017 № 7183-1. База даних «Законодавство Украӥни» / Верховна Рада Украіни. URL: http://w1.c1.rada.gov.ua/pls/zweb2/ webproc4 1?pf3511=62710.

6. Tsuguhito Omagari, Yuki Sako. Japan's New Crypto Regelation: 2019 Amendments to Payment Services Act and Financial Instruments and Exchange Act of Japan. URL: http://www.klgates.com/ stayinformed/.

7. 23 New York Codes, Rules and Regulations Part 200. URL: https://govt.westlaw.com/nycrr/ Browse/Home/NewYork/NewYorkCodesRulesand Regulations?guid=I7444ce80169611e594630000845 b8d3e\&originationContext=documenttoc\&transitio nType $=$ Default\&contextData $=($ sc. Default $)$.

8. Initial Coin Offerings and Crypto-Assents. Australian Securities and Investments Commission Official Web-Site. URL: https://asic.gov.au/ regulatory-resources/digital-transformation/initialcoin-offerings-and-crypto-assets/.

9. Recovery of Costs of Supervising Cryptoasset Businesses Under the Proposed Antimoney Laundering Regulations: Fees Proposals. Consultation Paper CP19/29. October, 2019. URL: https://www.fca.org.uk/publication/consultation/ cp19-29.pdf.

10. Regulations Amending Certain Regulations Made Under the Proceeds of Crime (Money Laundering) and Terrorist Financing. Act 2019: SOR/2019-240. URL: http://www.gazette.gc.ca/rp-pr/ p2/2019/2019-07-10/html/sor-dors240-eng.html. 
Serhii Fedorov. State control in the field of trading operations with cryptocurrencies: financial and legal aspect

The article is devoted to a general study of possible prospects and ways to introduce state control over the so-called trading operations with cryptocurrencies, in the financial and legal aspect. The author analyzes some features of the legal regulation of the use of cryptocurrencies (virtual currencies, crypto-assets) as financial instruments, the conduct of cryptocurrency trading and their exchange for fiat money. In this context, the article examines the new terminology used in this area, in particular, the concept of "cryptocurrency mining", "cryptocurrency trading", "blockchain" and so on.

The author of the article concludes that today cryptocurrencies are not only a means of payment that is widely used in various fields, but also a financial instrument that is actively "traded" on specialized cryptomarket and used in transactions for the exchange of fiat money. In order to streamline such relations, ensure their stability, ensure the protection of the rights and interests of participants in these relations, some countries have followed the path of recognizing cryptocurrencies as appropriate financial instruments, in connection with which streamlining relations on trade and cryptocurrency exchange is carried out market, use of securities and other financial instruments. Accordingly, the state control in this area is carried out by analogy with the state control of similar "normal exchange relations".

The article examines the need and possible ways to introduce state control over such financial transactions in Ukraine, for which a study of international experience of legislative regulation of trading transactions with cryptocurrencies, in particular, analyzes the regulations and recommendations of the US, Japan, Australia, UK, Canada in in this area. Based on the study, the general trends of state control over trading operations with cryptocurrencies as financial instruments in these countries are identified. The author investigates the possibilities of introducing this foreign experience of state control over trading operations with cryptocurrencies as financial transactions in Ukraine.

Key words: cryptocurrencies, cryptocurrency operations, trading operations, financial instruments, state control. 